\title{
REPRODUCTIVE BEHAVIOR AND SEASONAL OCCURRENCE OF Psecas viridipurpureus (SALTICIDAE, ARANEAE)
}

\author{
ROSSA-FERES, D. de C., ${ }^{1}$ ROMERO, G. Q., ${ }^{1,3}$ GONÇALVES-DE- FREITAS, E. ${ }^{1,2}$ and \\ FERES, R. J. F. ${ }^{1}$ \\ ${ }^{1}$ Departamento de Zoologia, Universidade Estadual Paulista, Rua Cristóvão Colombo, 2265, \\ Jd. Nazareth, CEP 15054-000, São José do Rio Preto, São Paulo, Brazil \\ ${ }^{2}$ Centro de Aqüicultura da Unesp (Caunesp) \\ ${ }^{3}$ Departamento de Zoologia, Universidade Estadual de Campinas, Unicamp \\ Correspondence to: Denise de C. Rossa-Feres, Departamento de Zoologia, Universidade Estadual Paulista, \\ Rua Cristóvão Colombo, 2265, Jd. Nazareth, CEP 15054-000, São José do Rio Preto, São Paulo, Brazil, \\ e-mail: denise@zoo.ibilce.unesp.br \\ Received January 4, 1999 - Accepted July 1, 1999 - Distributed May 31, 2000
}

(With 5 figures)

\begin{abstract}
The reproductive behavior and the seasonal occurrence of Psecas viridipurpureus were studied at the Estação Ecológica do Noroeste Paulista, a small conservation area in the northwest region of São Paulo State, Brazil (49 $22^{\prime} 50^{\prime \prime} \mathrm{W}$ and $20^{\circ} 48^{\prime} 36^{\prime}$ 'S). P. viridipurpureus occurred on "gravatá", a bromeliaceous plant (Bromelia balansae, Bromeliaceae) which does not accumulate rain water. During the courtship display the couple occupied the median region of the "gravatá" leaves, with the male always located in a higher position than the female. The males of $P$. viridipurpureus showed a complex courtship behavior, which included five motor patterns. The courtship and mating behavior occurred preponderantly during the rainy season and the juvenile recruitment between December and July. The retreat of $P$. viridipurpureus differs from the Salticidae pattern, since the egg sacs are covered with a plain silk cover and are not wrapped in cocoons.
\end{abstract}

Key words: seasonal occurrence, courtship behavior, reproductive biology, Salticidae, Psecas viridipurpureus.

\section{RESUMO}

\section{Comportamento reprodutivo e ocorrência sazonal de Psecas viridipurpureus (Salticidae, Araneae)}

O comportamento reprodutivo e a ocorrência sazonal de Psecas viridipurpureus foram estudados na Estação Ecológica do Noroeste Paulista, uma pequena área de conservação na região noroeste do Estado de São Paulo, Brasil (49²2'50”'W e 2048’36”S). P. viridipurpureus ocorreu em gravatás, uma bromeliácea (Bromelia balansae, Bromeliaceae) que não acumula água de chuva. Durante a exibição de corte, o casal ocupou a região mediana das folhas de gravatás, com o macho sempre localizado em uma posição superior à da fêmea. Os machos de $P$. viridipurpureus apresentaram um comportamento de corte complexo, que incluiu cinco padrões motores. O comportamento de corte e a cópula ocorreram preponderantemente durante a estação chuvosa e o recrutamento de jovens entre dezembro e julho. O abrigo de $P$. viridipurpureus difere do padrão de Salticidae, pois as ootecas são recobertas por uma cobertura de seda plana e não são incluídas em casulos.

Palavras-chave: ocorrência sazonal, comportamento de corte, biologia reprodutiva, Salticidae, Psecas viridipurpureus. 


\section{INTRODUCTION}

Salticid spiders are a conspicuous component of most terrestrial faunas, including about 4,000 described species living in a variety of biotopes (Jackson, 1982). It has been estimated that some 50 of the 400 salticid genera have had their courtship behavior studied in more or less detail (Jackson, 1978 in Robinson, 1982). However, the ecology and behavior of these spiders, mainly of the Brazilian species, remain poorly studied. As cursorial hunting spiders, salticids generally do not spin a web, but they often build silken retreats which are used as resting sites at night and during other periods of inactivity (Jackson, 1986). The females build silken cocoons, in which they deposit their egg sac and stay, probably exhibiting parental care of eggs or juveniles (Richman \& Jackson, 1992) or protecting themselves (Jackson, 1976). A few studies about the seasonal occurrence (Crane, 1949; Rinaldi \& Forti, 1997) suggest that the reproductive period of several salticid species is related to the beginning of the rainy season. According to Forster (1982), studies of salticids have proved that their courtship involves a real communication and that visual displays, which involve postures, movement and color patterns, play a major role.

The courtship behavior of Psecas viridipurpureus Simon, 1901 (Araneae, Salticidae) has not been previously described and nothing is known about its seasonal occurrence. Thus, we describe here for the first time, the reproductive behavior and seasonal occurrence of one population of $P$. viridipurpureus that occurs on "gravatás" (Bromelia balansae Mez., Bromeliaceae), a bromeliaceous plant which does not accumulate rain water, in the nortwestern region of São Paulo State, Brazil.

\section{MATERIAL AND METHODS}

This study was conducted at the Estação Ecológica do Noroeste Paulista (EENP), a small conservation area located in the northwest region of São Paulo State $\left(49^{\circ} 22^{\prime} 50^{\prime \prime} \mathrm{W}\right.$ longitude and $20^{\circ} 48^{\prime} 36$ "S latitude), Brazil. The climate is seasonal, with a rainy season from October to March and a pronounced dry season from April to September, which receives only $15 \%$ of the annual precipitation (Arid \& Barcha, 1973). The EENP presents frag- ments of semidecidous seasonal forest intermingled with pasture areas. Three areas were selected based on "gravatá" population abundance: two pasture areas of about $150 \mathrm{~m}^{2}$ with 30 "gravatás" in each, and a $120 \mathrm{~m} \times 2.5 \mathrm{~m}$ area along a trail, with a population of about 50 "gravatás".

The seasonal occurrence of $P$. viridipurpureus was determined by monthly or bimonthly naturalistic observations carried out from August 1996 to September 1997. On each visit the gravatás were scrutinized in order to record the presence of juveniles, couples, and egg sacs and the occurrence of courtship and copulation. Based on these observations, it was possible to establish categories for the abundance of couples in the studied areas: rare $=1-3$ couples, little abundant $=4-7$ couples, abundant $=8-12$ couples, very abundant $=$ more than 12 couples. The precipitation and temperature data were obtained from a Meteorological Station located $4 \mathrm{~km}$ from EENP. Voucher specimens (three males and three females) were deposited in the Arachnological Collection of the Laboratório de Artrópodes Peçonhentos, Instituto Butantã (IBSP-16242).

At first, the description of the reproductive behavior was based on observations carried out in the field, according to the animal focal method (Martin \& Bateson, 1986).

In the laboratory, five couples were kept separately in $65 \times 40 \times 50 \mathrm{~cm}$ terraria each containing a potted "gravatá". In order to quantify the duration and frequency of the behavioral units, each couple was transfered to a $50 \times 25 \times 15 \mathrm{~cm}$ glass box, and the courtship and mating behavior was video-recorded.

\section{RESULTS}

Only one couple of Psecas viridipurpureus was recorded per plant. Mating and courtship activities occurred from August 1996 to March 1997. The highest abundance of couples was observed from November to January (Table 1). Occurrence of egg sacs was recorded from November 1996 to March 1997 and in July 1997, and juvenile recruitment occurred from December 1996 to July 1997 (Fig. 1).

During the courtship display the couple occupied the middle region of the "gravatá" leaves, with the male located in a higher position than the female ( $n=25$, Fig. 2). 


\section{TABLE 1}

Monthly abundance categories of couples of Psecas viridipurpureus on "gravatás" at EENP, northwest region of São Paulo State, from August 1996 to September 1997.

\begin{tabular}{|c|c|c|c|c|}
\hline & Rare & Little abundant & Abundant & Very abundant \\
\hline August & & $\mathrm{X}$ & & \\
\hline September & & $\mathrm{X}$ & $\mathrm{X}$ & $\mathrm{X}$ \\
\hline October & & & & $\mathrm{X}$ \\
\hline November & & & & \\
\hline December & & & & \\
\hline January & & & & \\
\hline February & & $\mathrm{X}$ & \\
\hline March & $\mathrm{X}$ & $\mathrm{X}$ & & \\
\hline April & $\mathrm{X}$ & & & \\
\hline May & $\mathrm{X}$ & $\mathrm{X}$ & & \\
\hline June & & & & \\
\hline July & & $\mathrm{X}$ & & \\
\hline August & & & & \\
\hline September & & & & \\
\hline
\end{tabular}

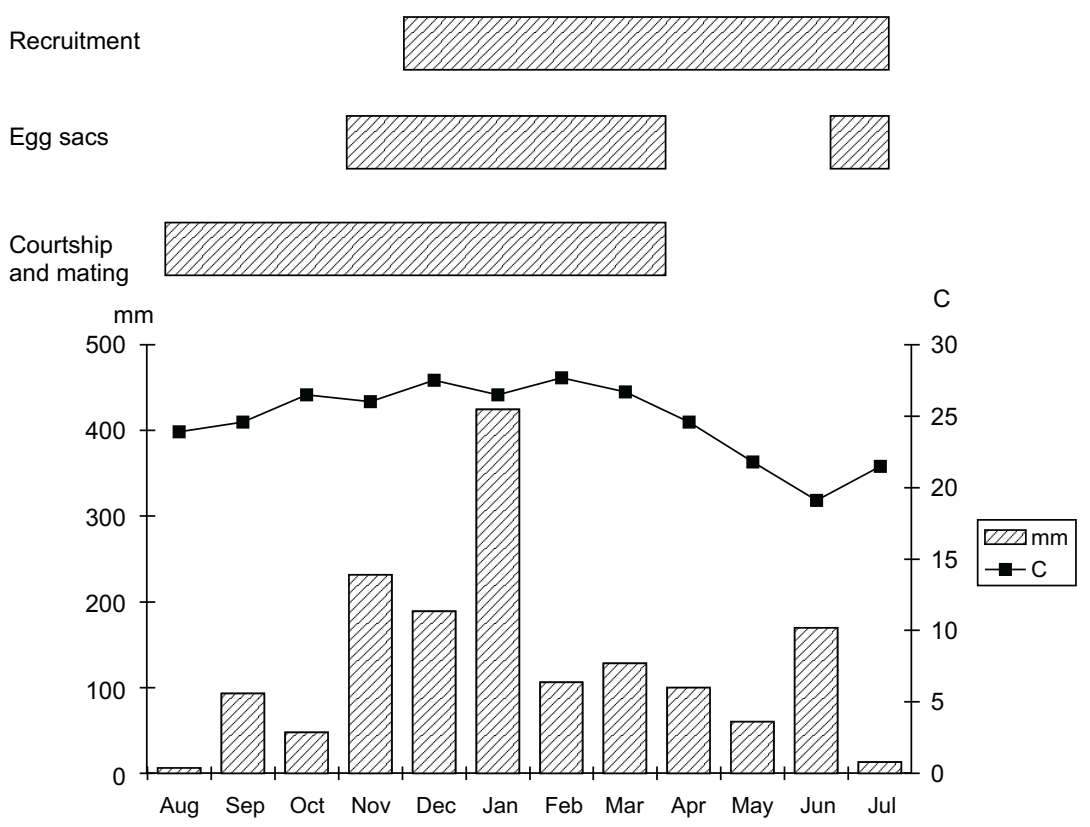

Fig. 1 - Seasonal occurrence and reproductive activity of Psecas viridipurpureus, monthly precipitation and median temperature at EENP, northwest region of São Paulo State, from August 1996 to July 1997.

The same spatial location was observed in the terrarium and in the glass box $(\mathrm{n}=20)$. The male of $P$. viridipurpureus showed a reproductive behavior which was divided into three categories and five behavioral units. The following ethogram was based on movement patterns described by Jackson (1982). 


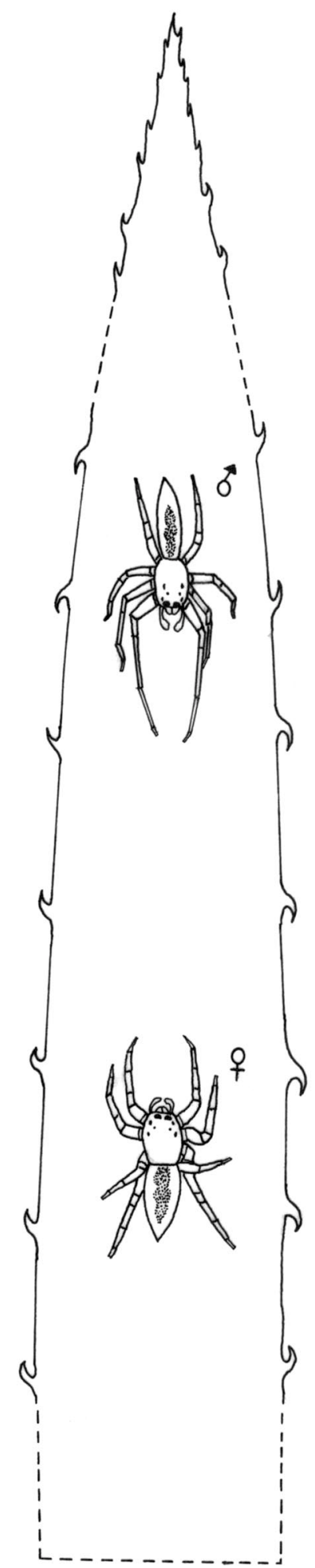

Fig. 2 - Microspatial location of male and female Psecas viridipurpureus during the courtship, which occurs on the middle region of the "gravatá" leaf. 
1. COURTSHIP: early mating movements displayed toward the female. This category was divided into five behavioral units.

1.1. Linear approaching: the male moves toward the female performing some pauses during the course. Such movement results in couple approaching.

1.2. Zig-zag: the male moves side-to-side around the female in a zig-zag way, with the first pair of legs elevated at a $45^{\circ}$ in angle from the substrate.

1.3. Bending: the male spreads forward the first two pairs of legs, which stay close to the substrate and directed toward the female, and keeps the last two pairs deflected. It bends the body laterally and moves slowly to the bent side. During such movement, the first pair of legs and the opisthosoma are in a position opposite to the displacement, and the male's body assumes a "comma-like" shape.

1.4. Standing: without any displacement, the male elevates the first pair of legs to an angle of about $45^{\circ}$ from the substrate and puts the tarsi slowly forward the prosoma, vibrating them slightly and putting them so closed or jointed. The opisthosoma may not be elevated.

1.5. Pre-mating approach: the male approaches to the female and touches it using the first pair of legs.

2. MATING: the male mounts the female on her side, staying in an opposite and parallel position to the female, and inserts its emboli into the epyginum opening.

3. FLEEING: the male departs quickly from the female after any attack or after mating.

We recorded 20 full courtship sequences (from linear approaching to pre-mating approaching) for the five couples observed. This sequence lasted $3.25 \pm 1.5 \mathrm{~min}$. Zig-zag was the most frequent behavioral unit of the courtship display and bending was the least frequent unit, which was recorded only for two couples (Fig. 3).

The same sequence of courtship and mating behavior occurred in the natural and in the artificial environment. The behavior began with the male approaching (linear approaching) and resulted in mating and/or fleeing (Fig. 4). Only one couple was observed to mate in the glass box, but all couples mated in the terrarium, where we recorded even 5 mating events for a single couple and one egg sac for each female. After mating, the males fled and the females moved to the base of the "gravatá" leaves.

We recorded no more than two egg sacs in the concave upper side of the "gravatá" leaf. Such egg sacs were positioned in a middle direction along the leaf and were covered with a plain silk cover, spun from edge to edge of the leaf (Fig. 5). Females wer observed to stay under this cover several times. A thick cover was webbed by males and females when egg sacs were absent.

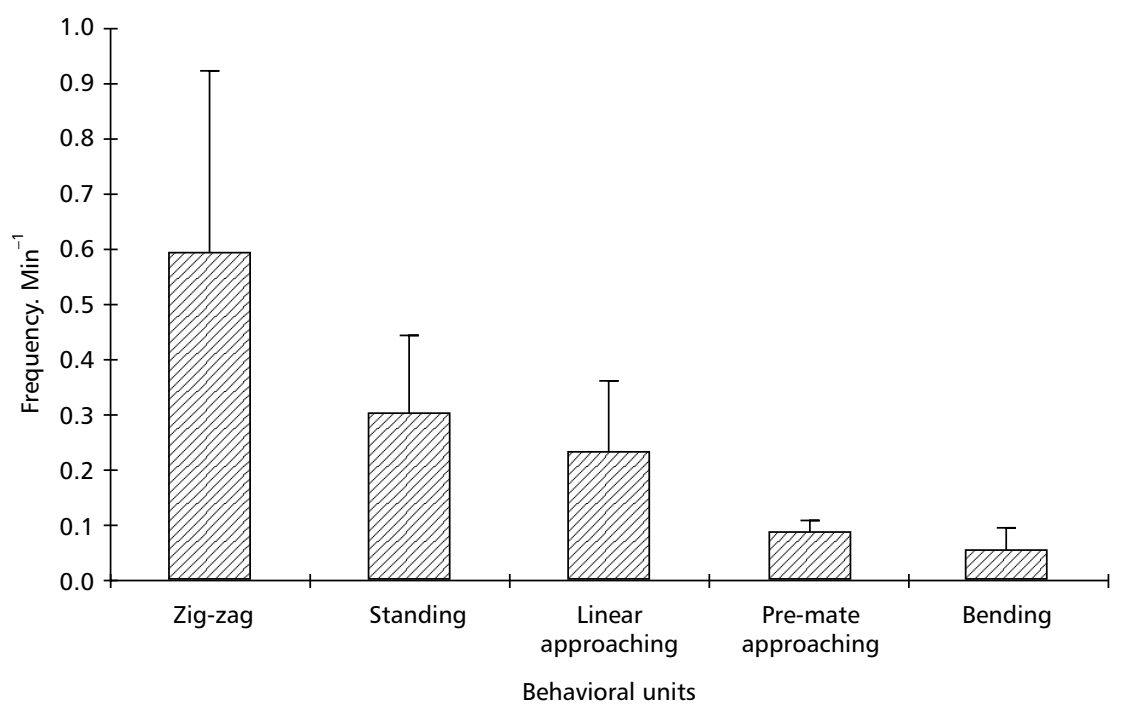

Fig. 3 - Frequency (mean \pm standard deviation) of the courtship behavioral units displayed by the males of Psecas viridipurpureus. 


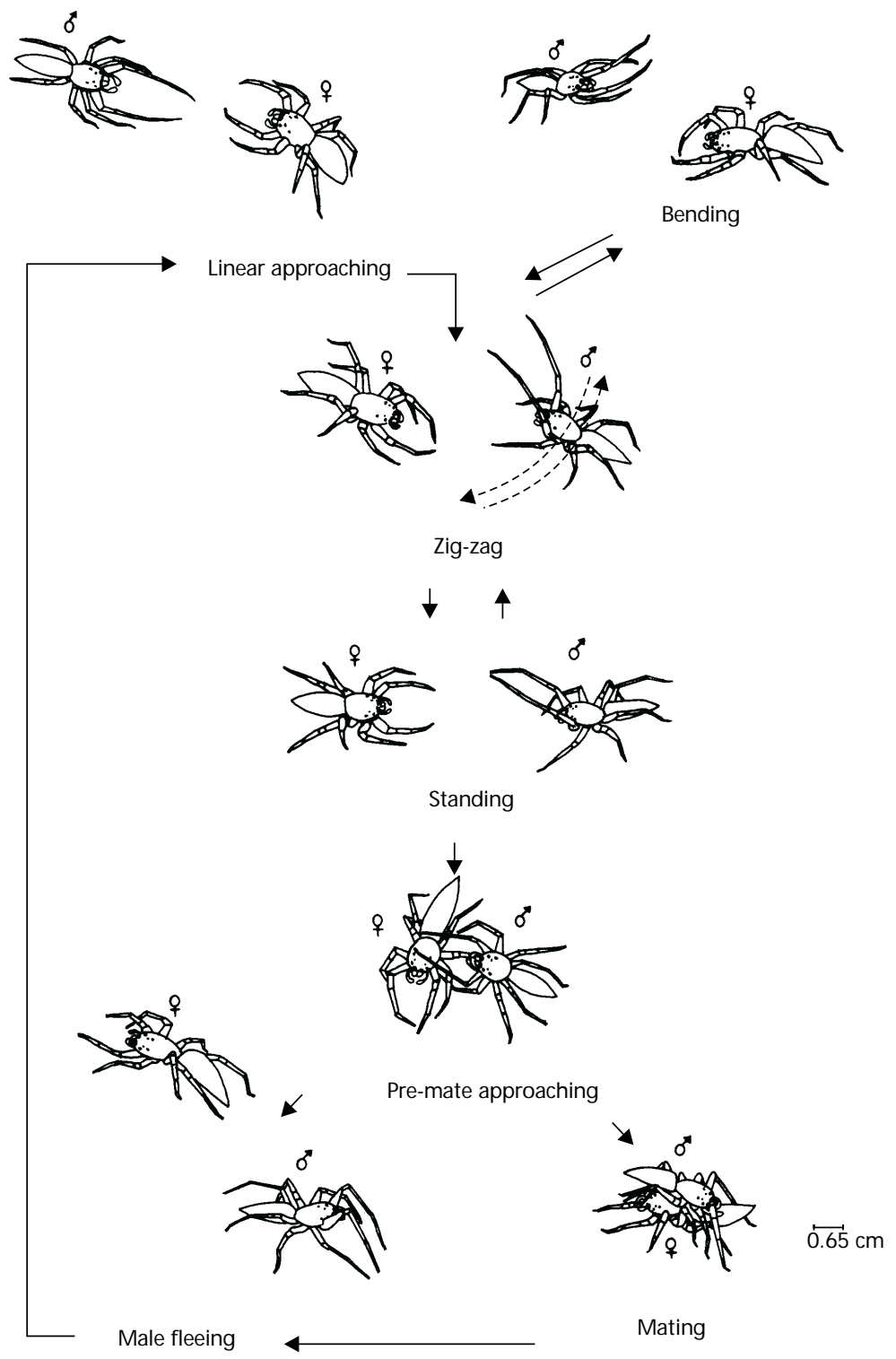

Fig. 4 - Sequence of courtship and mating behavior displayed by Psecas viridipurpureus.

We did not find juveniles of $P$. viridipurpureus on the "gravatás" in the field. In the terrarium we observed that the young spiders emerge from the egg sac with a pale body, and about one month later, their body coloration changes to a color like that of the adult female's body, which has a reddish opisthosoma with a green band on the cardiac region. The particular color pattern of the males (black with silvered spots) arises just in subadult males, which still keep a vestige of the red color in the apical part of the opisthosoma.

\section{DISCUSSION}

The occurrence and reproductive period of Psecas viridipurpureus seem to be influenced by climate since the courtship and mating behavior occurred in the rainy season. 


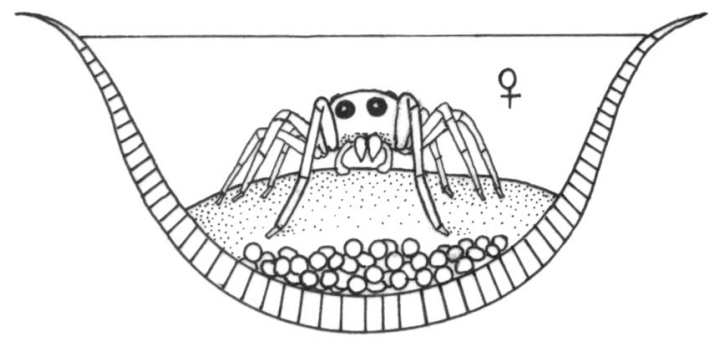

Fig. 5 - Scheme of egg sac and plain silken cover spun by Psecas viridipurpureus on the "gravatá" leaf (Bromelia balansae).

According to Crane (1949), many salticids from Rancho Grande, Venezuela, have a peak of reproduction during the beginning of the rainy season. According to Rinaldi \& Forti (1997), most of the hunting spiders from the studied fragment of rainy forest occur during the warm and wet months.

The period of reproductive activity of $P$. viridipurpureus and "gravatás" seems to be synchronic. The peak of courtship and mating (from November to January) coincides with flowering period of Bromelia balansae, when the central rosette changes from a green to a red color (Neusa Taroda-Ranga, personal communication). Thus, the red color of the female may contribute to its camouflage, since the location of couples on "gravatá" leaves and the movements during courtship can make them susceptible to predation (see Platnick, 1971 and Jackson, 1976).

The behavioral units observed for $P$. viridipurpureus were similar to the movement pattern described by Jackson (1982) for salticid spiders.

Moreover, the behavior observed in the laboratory was identical to that observed in the natural environment, except for the amplitude of the zig-zag movement, which was wider on the glass wall of the boxes than on the "gravatá" leaves, where there was a narrower surface for side-to-side displacement. Crane (1949) also observed no differences in reproductive behavior in captivity and in the natural environment for 13 species of salticids which she had studied in Venezuela. According to Jackson (1982), the zig-zag behavior (the most frequent unit in P. viridipurpureus) is relatively stereotyped in Phidippus johnsoni. It is the male first display toward the female and should be important to brake the hunting stimulus by the female. However, Crane (1949) pointed such display as necessary to stimulate the female for reproduction.

Jackson (1981) emphasized that courtship is a feature of sexual selection in salticids, and the female chooses the male which shows the most elaborate behavior. Courtship is important also for specific recognition, female mating stimulation and cannibalism reduction (Jackson, 1982). Although fleeing was not included by Jackson (1982) in the behavioral repertory, we considered it another item promoting reduction of female cannibalism.

According to Richman \& Jackson (1992), the salticid egg sac usually is a spherical egg mass surrounded by a thick silk layer and included in a cocoon. The retreat of $P$. viridipurpureus differs from the Salticidae pattern, since the egg sacs are covered with a plain silk cover and are not included in cocoons. Since we did not observe juveniles on the "gravatás", two hypotheses may be postulated: they disperse, returning to the plants at the end of the dry season or stay at the base of the leaves, where it is very difficult to see them.

Acknowledgments - The authors thank Dr. Antônio D. Brescovit, Setor de Artrópodes Peçonhentos, Instituto Butantan, São Paulo, for Psecas species identification; Drs. João Vasconcellos Neto and José Roberto Trigo, Departamento de Zoologia, Unicamp, Dra. Isabela M. P. Rinaldi, Departamento de Zoologia and André A. Stropa, PósGraduação em Zoologia, Unesp, Botucatu, for their critical review of the manuscript and helpful suggestions. Figures 2, 4 and 5 were drawn by Welington Forster. 


\section{REFERENCES}

ARID, F. M. \& BARCHA, S. F., 1973, Água subterrânea na formação Bauru - região norte-ocidental do Estado de São Paulo. Boletim de Ciências da Faculdade de Filosofia, Ciências e Letras, São José do Rio Preto, 1: 70-101.

CRANE, J., 1949, Comparative biology of salticid spiders at Rancho Grande, Venezuela. Part IV. An analysis of display. Zoologica, New York, 34(17): 159-215.

FORSTER, L., 1982, Visual communication in jumping spiders (Salticidae). In: P. N. Witt \& J. S. Rovner (eds.), Spider Communication: Mechanisms and Ecological Significance. Princeton University Press, New Jersey, pp. 161-212.

JACKSON, R. R., 1976, Predation as a selection factor in the mating strategy of the jumping spider Phidippus johnsoni (Salticidae, Araneae). Psyche, Cambridge, (September-December), pp. 243-255.

JACKSON, R. R., 1981, Relationship between reproductive security and intersexual selection in a jumping spider Phidippus johnsoni (Araneae, Salticidae). Evolution, Lawrence, 35(3): 601-604.

JACKSON, R. R., 1982, The behavior of communicating in jumping spiders (Salticidae), In: P. N. Witt \& J. S. Rovner (eds.), Spider Communication: Mechanisms and Ecological Significance. Princeton University Press, New Jersey, pp. 231-247.
JACKSON, R. R., 1986, The display behaviour of Bavia aericeps (Araneae: Salticidae), a jumping spider from Queensland. Aust. J. Zool., Sydney, 34: 381-409.

MARTIN, P. \& BATESON, P., 1986, Measuring behavior: an introductory guide. Cambridge University Press, Cambridge, New York, Melbourne and Sydney, 200p.

PLATNICK, N., 1971, The evolution of courtship behaviour in spiders. Bull. Brit. Arach. Soc., London, 2(3): 40-47.

RICHMAN, D. B. \& JACKSON, R. R., 1992, A review of the ethology of jumping spiders (Araneae, Salticidae). Bull. Brit. Arach. Soc., London, 9(2): 33-37.

RINALDI, I. M. P. \& FORTI, L. C., 1997, Hunting spiders of woodland fragments and agricultural habitats in the Atlantic rain forest region of Brazil. Stud. Neotrop. Fauna \& Environm., Tübingen, 32: 1-12.

ROBINSON, M. H., 1982, Courtship and mating behavior in spiders. Ann. Rev. Entomol., Palo Alto, 27: 1-20. 